\title{
CMAJ 2011 election survey: electronic health records
}

$\mathrm{P}$ eople often use the words "health" and "medical" interchangeably, often without consequence, on the presumption that everyone knows what everyone is talking about.

The distinction, though, can create major difficulties, particularly in terms of people's comprehension, as evidenced by debate surrounding Canada's multibillion investment in the development of electronic record systems for health, or medicine, as the case may be.

Canada Health Infoway, the agency responsible for the development of a national information infrastructure (or infostructure, as many refer to it), views the concept of Electronic Health Records (EHRs) as being completely distinct from Electronic Medical Records (EMRs).

The former, EHRs, refers to the national electronic architecture, says the agency, which argues that the development of an "interoperable" national infostructure is its primary responsibility. When completed, that national architecture would primarily be used to aggregate health information in such a way that it would be valuable for policy-makers and researchers.

The agency sees the latter concept of EMRs, by contrast, as record-keeping systems at the doctor-patient level that would be used primarily as an aid in the clinical diagnosis and treatment of disease.

That the two concepts are, in a manner of speaking, worlds apart, is demonstrated by an ongoing $C M A J$ series which has indicated that there is a fundamental disconnect by Canada Health Infoway's plan for a national EHR system and an EMR model that be useful at the physician-patient level. Even an Infoway-commissioned performance evaluation reached that conclusion (www.cmaj.ca/cgi/doi/10.1503 /cmaj.109-3860).

The two concepts are also often at the root of rationalizations or squabbles over responsibilities within the system.

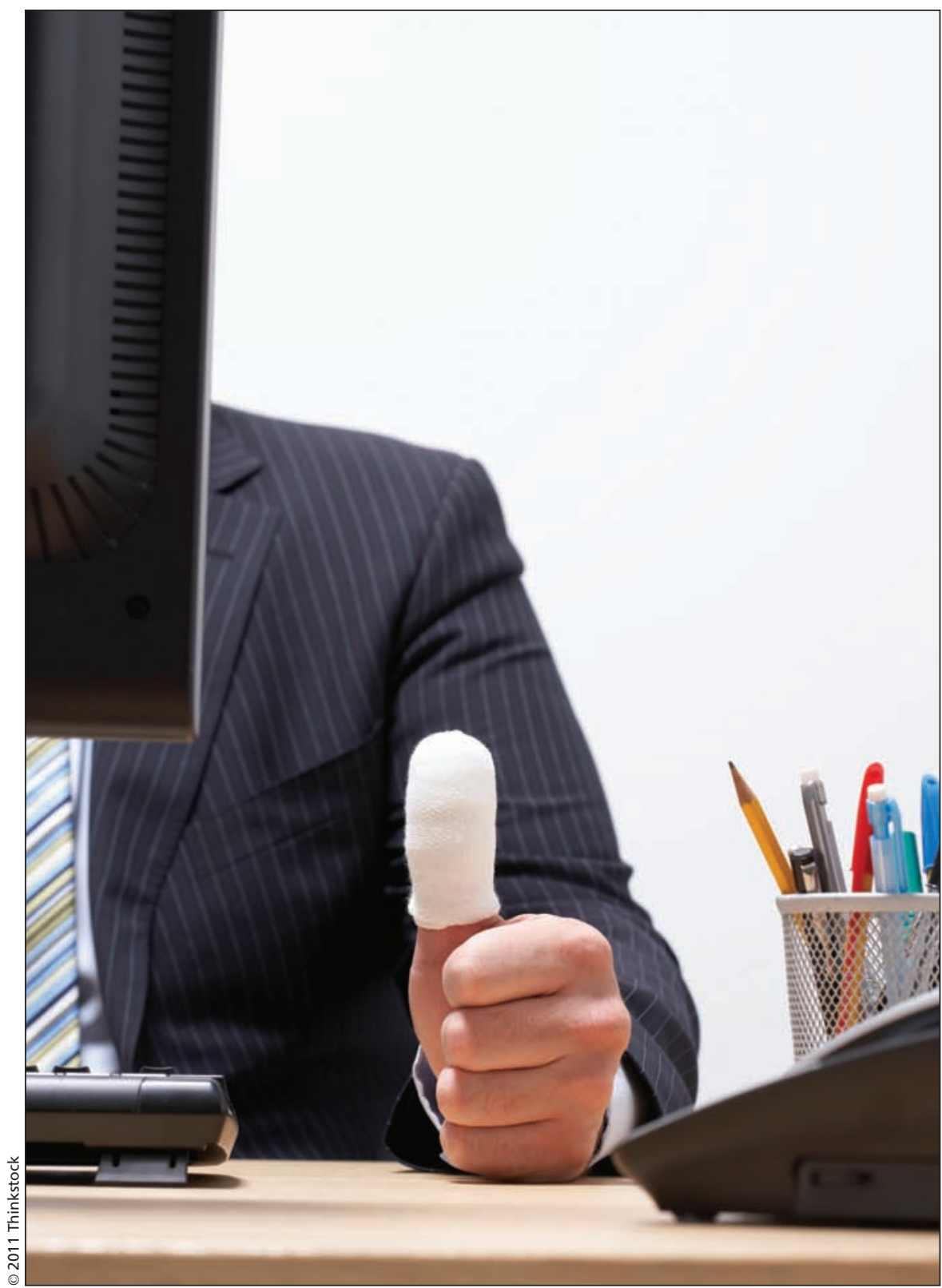

Something is broken in the hand that's guiding development of a national electronic health information system, experts say.

Canada Health Infoway is quick to essentially argue that EMRs are the responsibility of provinces. The provinces and territories, along with various academic and medical professional voices, are as quick to chide Canada Health Infoway for policies and programs that are aimed at nebulous objectives that have little to do with medical treatment.
It's raised a raft of questions about Canada's strategy in developing a health information system, including:

- The advisability of using industrial policy, rather than health system needs, to drive development of the system (www.cmaj.ca/cgi/doi/10 .1503/cmaj.109-3717).

- The wisdom of Canadian planners in 
rejecting an approach using systems based on free "open-source" software in favour of a multitude of pricier "proprietary-source" software products in order to stimulate Canada's software industry (www.cmaj.ca/cgi /doi/10.1503/cmaj.109-3717).

- The consequences of failing to develop and implement national standards for software and equipment that are to be part of the national architecture (www.cmaj.ca/cgi/doi /10.1503/cmaj.109-3239).

- The differences between Canadian and international approaches in developing the system, particularly the adoption of "meaningful use" provisions in purchasing programs in other nations to ensure that physicians and patients actually benefit from capital investments (www.cmaj .ca/cgi/doi/10.1503/cmaj.109-3361).

So divided are opinions on Canada's approach that some have accused Canada Health Infoway of building a "Tower of Babel," while others have argued that the situation is now so incoherent that what is needed is some manner of national "watchdog" to assess government ehealth efforts (www.cmaj .ca/cgi/doi/10.1503/cmaj.109-3783). Still others contend that the national strategy needs desperately to be refocused.

Canada's political parties appear unconvinced, as all essentially duck the issue of whether change is needed.

The Conservative Party declined to participate in the CMAJ survey and while in office, has demonstrated no inclination whatsoever to in any way address the issue.

The Liberals offer little more than a vague promise: "to accelerate the use of electronic health records by health care professionals, and to ensure that all
Canadians benefit from electronic health records.

The New Democrats, meanwhile, say they would examine the current situation before determining what remedial measures are needed, while the Bloc Québécois says that whatever changes are made, the province must remain the "prime contractor." — Wayne Kondro, CMAJ

Survey question: What changes would your party make to Canada Health Infoway and its current strategy for implementing electronic medical records?

\section{Conservative response:}

No response. Rather than participate in CMAJ's 2011 election survey, the Conservatives forwarded a weblink to their party platform. Asked what the rationale was for declining participation, party spokesperson Ryan Sparrow says the weblink constitutes a response to the survey. "That response is the response from the campaign."

\section{Liberal response:}

"A Liberal government will work with doctors, nurses and health practitioners to accelerate the use of electronic health records by health care professionals, and to ensure that all Canadians benefit from electronic health records."

\section{New Democrat response:}

"Electronic medical records and their companion electronic health records provide a vital tool in improving the health care of Canadians. However the implementation of new technological systems quite often can be improved. However before a New Democrat government would propose any changes to the current implementation of the Canada Health Infoway we would conduct an evaluation of the current system to identify improvements and efficiencies."

Bloc Québécois response:

"Comme vous le savez, le gouvernement du Québec participe activement à Inforoute Santé Canada depuis 2004. Si des changements sont proposés pour Inforoute Santé, le Québec doit demeurer le maître d'œuvre de ses actions."

CMAJ 2011. DOI:10.1503/cmaj.109-3881

Editor's note: Ninth of a series of stories on CMAJ's 2011 election survey:

Part 1: Health transfers (www.cmaj.ca/cgi/doi/10.1503/cmaj.109-3865)

Part 2: Pharmacare (www.cmaj.ca/cgi/doi/10.1503/cmaj.109-3870)

Part 3: Health human resources (www.cmaj.ca/cgi/doi/10.1503/cmaj.109-3875)

Part 4: Home/palliative care (www.cmaj.ca/cgi/doi/10.1503/cmaj.109-3876)

Part 5: Research (www.cmaj.ca/cgi/doi/10.1503/cmaj.109-3877)

Part 6: Food safety (www.cmaj.ca/cgi/doi/10.1503/cmaj.109-3878)

Part 7: Transparency (www.cmaj.ca/cgi/doi/10.1503/cmaj.109-3879)

Part 8: Public health (www.cmaj.ca/cgi/doi/10.1503/cmaj.109-3880)

Translations by Wayne Kondro, CMAJ 